
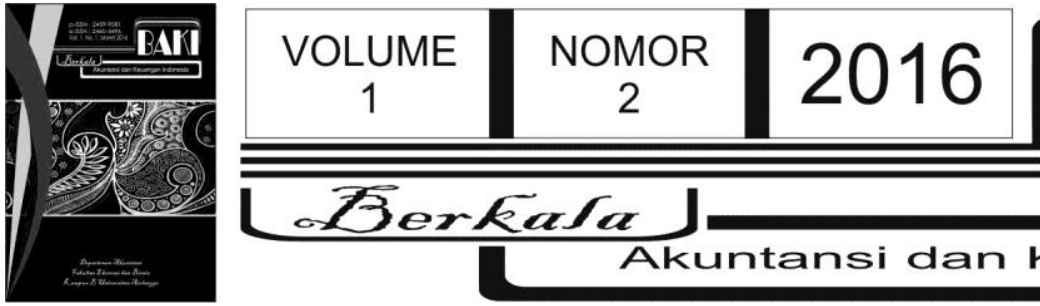

Lerkata

Akuntansi dan Keuangan Indonesia

\title{
Analisis Faktor-Faktor Kepatuhan Wajib Pajak Orang Pribadi Pelaku Usaha Pada KPP Pratama Salatiga
}

\author{
Devira Nourma Anjani, MI Mitha Dwi Restuti
}

*Universitas Kristen Satya Wacana

*mitha.restuti@staff.uksw.edu

\begin{tabular}{|c|c|}
\hline INFOARTIKEL & A B S TRAK \\
\hline $\begin{array}{l}\text { Histori Artikel: } \\
\text { Tanggal Masuk } 2 \text { Mei } 2016 \\
\text { Tanggal Diterima } 26 \text { Agustus } \\
2016 \\
\text { Tersedia Online } 30 \text { September } \\
2016 \\
\text { Kata Kunci: } \\
\text { sikap; } \\
\text { norma subyektif; } \\
\text { kontrol perilaku yang } \\
\text { dipersepsikan; } \\
\text { niat; } \\
\text { kepatuhan pajak }\end{array}$ & $\begin{array}{l}\text { Tujuan dari penelitian ini yaitu untuk menganalisis faktor-faktor } \\
\text { yang mempengaruhi kepatuhan wajib pajak orang pribadi dengan } \\
\text { diberlakukannya PP No. } 46 \text { Tahun } 2013 \text {. Selain itu, penelitian ini } \\
\text { juga bertujuan untuk menganalisis interaksi antara sikap, norma } \\
\text { subyektif, dan kontrol perilaku yang dipersepsikan. Jumlah sampel } \\
\text { yang digunakan adalah } 103 \text { orang wajib pajak orang pribadi } \\
\text { pelaku usaha tertentu yang terdaftar pada KPP Pratama Kota } \\
\text { Salatiga. Teknik pengambilan sampel dengan cara purposive } \\
\text { sampling untuk selanjutnya diolah menggunakan SPSS AMOS } \\
\text { 22.0. Hasil penelitian ini menunjukkan bahwa (1) tidak terdapat } \\
\text { interaksi atau hubungan antara sikap, norma subyektif dan kontrol } \\
\text { perilaku yang dipersepsikan; (2) sikap berpengaruh positif secara } \\
\text { signifikan terhadap niat untuk berperilaku patuh; (3) norma } \\
\text { subyektif tidak berpengaruh signifikan terhadap niat berperilaku } \\
\text { patuh; (4) kontrol perilaku yang dipersepsikan berpengaruh positif } \\
\text { secara signifikan terhadap niat berperilaku patuh; (5) kontrol } \\
\text { perilaku yang dipersepsikan berpengaruh langsung terhadap } \\
\text { kepatuhan pajak; dan (6) niat berperilaku patuh berpengaruh } \\
\text { terhadap kepatuhan pajak. }\end{array}$ \\
\hline
\end{tabular}

\section{Pendahuluan}

Penerimaan negara digunakan untuk membiayai pengeluaran pemerintah dan pembangunan nasional. Sebagai negara berkembang, Indonesia memerlukan adanya pembangunan nasional agar dapat tetap bersaing dengan negara berkembang lainnya. Jika pengeluaran pemerintah meningkat, maka pemerintah harus berupaya untuk menaikkan penerimaan pajak. Hal ini karena pajak merupakan penyumbang penerimaan negara yang paling besar. Peran pajak bagi bangsa amatlah besar, kontribusi penerimaan pajak terhadap APBN mencapai lebih dari tujuh puluh tujuh persen (DJP 2013).

Di Indonesia menganut sistem Self Assesment System yang artinya wajib pajak diberi kepercayaan, kesempatan untuk menghitung sendiri jumlah pajak terhutang, memperhitungkan 
jumlah pajak yang sudah dibayar dan melaporkan sendiri kewajiban perpajakannya. Adapun peran fiskus yaitu sebagai pihak yang mengawasi (Sumantry dalam Sulistiyono 2012). Pemerintah tampaknya akan terus menaikkan target penerimaan pajak, dengan alasan tax ratio (perbandingan antara jumlah pajak yang berhasil dipungut dengan total penerimaan negara) dan coverage ratio (perbandingan antara besar realisasi pajak dengan potensi yang ada) di Indonesia masih rendah. Menurut Gusfahmi (2011), angka tax ratio Indonesia masih terlalu rendah jika dibandingkan dengan negara Asia lainnya.

Salah satu upaya pemerintah meningkatkan penerimaan pajak yaitu dengan memungut pajak dari Usaha Mikro Kecil Menengah (UMKM). Alasan pemerintah memungut pajak dari UMKM karena mereka memiliki potensi untuk meningkatkan pertumbuhan perekonomian nasional. Bisnis UKM memiliki peranan penting di sektor perekonomian Indonesia. William (2012) menyatakan bahwa hal tersebut disebabkan bisnis UKM merupakan unit bisnis terbesar dalam penyerapan tenaga kerja maupun pembentuk PDB Nasional. Sektor informal termasuk UKM telah menggenjot pertumbuhan ekonomi Indonesia ke arah membaik. Namun demikian, kontribusi penerimaan pajak dari sektor informal tersebut masih di bawah 2 persen (Kompas 2014). Potensi penerimaan pajak UKM di Indonesia kurang lebih bisa mencapai tujuh puluh lima triliun Rupiah per tahun (Tribunnews 2014). Walaupun pajak yang terutang untuk UMKM tidak sebesar perusahaan-perusahaan nasional atau multinasional, tetapi menurut Harian Bisnis Indonesia dalam William (2012) menyatakan bahwa UKM terbukti tahan terhadap krisis dan mampu survive karena tidak memiliki utang luar negeri, tidak banyak utang ke perbankan karena mereka dianggap unbankable, menggunakan input lokal, dan berorientasi ekspor. Jumlah UMKM di Indonesia saat ini belum terdata dengan jelas, sehingga nilai penerimaan pajak UKM yang mulai diberlakukan per 1 Juli 2013 tidak bisa ditargetkan secara pasti (Neraca 2014).

Kepatuhan Wajib Pajak adalah faktor penting dalam merealisasikan target penerimaan pajak. Semakin tinggi kepatuhan wajib pajak, maka penerimaan pajak akan semakin meningkat, demikian pula sebaliknya (DJP 2013). Penerapan self-assessment diharapkan dapat meningkatkan kepatuhan wajib pajak dalam melaksanakan kewajiban perpajakannya sesuai dengan ketentuan perpajakan yang berlaku. Syahdan dan Rani (2013) menyatakan bahwa banyak perilaku ketidakpatuhan dalam melaksanakan kewajiban perpajakan akibat mengalami kesulitan dalam memahami administrasi perpajakan. Wajib pajak yang tidak memahami administrasi perpajakan akan cenderung melakukan upaya penghindaran pajak. Maka dari itu, untuk memberikan kemudahan dalam penyederhanaan penghitungan pajak, Pemerintah mengeluarkan Peraturan Pemerintah Nomor 46 Tahun 2013. Pemberlakuan PP No. 46 Tahun 2013 dimaksudkan untuk memenuhi target penerimaan pajak. Peraturan ini mengatur para pengusaha perorangan atau badan non-BUT dengan peredaran bruto tertentu 
yang dikenakan tarif sebesar satu persen. Kebijakan tersebut diharapkan dapat mengedukasi masyarakat untuk tertib administrasi dan transparansi, serta memberikan kesempatan bagi masyarakat untuk berkontribusi dalam penyelenggaraan negara.

Penelitian tentang kepatuhan pajak telah banyak dilakukan, antara lain Bobek dan Hatfield (2003), Mustikasari (2007), dan Tarjo (2009). Penelitian tersebut menggunakan model TPB sebagai variabel dalam penelitian. Perbedaan penelitian ini dengan penelitian Bobek dan Hatfield (2003) dan Tarjo (2009) yaitu terletak pada lokasi dan objek penelitian. Penelitian ini dilakukan di Salatiga, Jawa Tengah dengan objek yaitu Wajib Pajak Orang Pribadi pengusaha tertentu. Variabel yang digunakan pada penelitian ini lebih berfokus pada model Theory of Planned Behavior (TPB). Variabel Tarjo (2009) ditambah dengan kewajiban moral dan Mustikasari (2007) dengan menambahkan variabel kewajiban moral, kondisi keuangan, fasilitas perusahaan, dan iklim organisasi. Oleh karena itu, untuk menjelaskan perilaku Wajib Pajak Orang Pribadi, penelitian ini memfokuskan model TPB sebagai faktor-faktor yang mempengaruhi kepatuhan wajib pajak dan menginteraksikan antar variabel independennya.

Penelitian ini bertujuan untuk mengetahui faktor-faktor yang mempengaruhi kepatuhan Wajib Pajak Orang Pribadi pengusaha tertentu dalam memenuhi kewajiban perpajakannya sesuai dengan PP No. 46 Tahun 2013 di Kantor Pelayanan Pajak Pratama Kota Salatiga. Faktor-faktor yang mempengaruhi kewajiban perpajakan diambil dari Theory of Planned Behavior (TPB), yaitu sikap, norma subyektif, kontrol perilaku yang dipersepsikan dan niat.

\section{Tinjauan Pustaka}

\subsection{Theory of Planned Behavior (TPB)}

Penelitian ini menggunakan teori yang mengadopsi hasil penelitian dari Icek Ajzen. TPB merupakan hasil pengembangan dari teori sebelumnya yang dicetuskan oleh Ajzen dan Fishbein yaitu Theory of Reasoned Action (TRA). TRA disusun menggunakan asumsi dasar bahwa manusia berperilaku dengan sadar dan mempertimbangkan segala informasi yang tersedia (Ramdhani 2007). TRA menjelaskan bahwa suatu perilaku muncul karena seseorang mempunyai niat atau keinginan untuk melakukannya (behavioral intention). Ajzen (1980) menyatakan bahwa niat seseorang untuk melakukan suatu perilaku akan menentukan perilaku tersebut. Niat untuk melakukan perilaku tertentu dipengaruhi oleh sikap (attitude towards behavior) dan pengaruh sosial yaitu norma subyektif (subjective norms).

Penelitian Ajzen (1991) menggunakan kerangka kerja konseptual (Gambar 1) yang berguna untuk menghadapi kompleksitas perilaku sosial manusia. Pada TPB, Ajzen menambahkan kontrol perilaku yang dipersepsikan sebagai dasar kepercayaan terhadap 
perilaku. Selain itu, Ajzen (1991) juga menyatakan bahwa sikap terhadap perilaku, norma subyektif sehubungan dengan perilaku, dan kontrol perilaku yang dipersepsikan biasanya digunakan untuk memprediksi niat perilaku dengan tingkat akurasi yang tinggi. Tiga faktor penentu dari niat berperilaku yaitu:

a) behavioral beliefs, yaitu keyakinan individu akan hasil dari suatu perilaku dan evaluasi atas hasil tersebut (beliefs strength and outcome evaluation),

b) normative beliefs, yaitu keyakinan tentang harapan normatif orang lain dan motivasi untuk memenuhi harapan tersebut (normative beliefs and motivation to comply), dan

c) control beliefs, yaitu keyakinan tentang keberadaan hal-hal yang mendukung atau menghambat perilaku yang akan ditampilkan (control beliefs) dan persepsinya tentang seberapa kuat hal-hal yang mendukung dan menghambat perilakunya tersebut (perceived power). Hambatan yang mungkin timbul pada saat perilaku ditampilkan dapat berasal dari dalam diri sendiri maupun dari lingkungan.

Ajzen (2006) menyatakan bahwa sikap terhadap perilaku positif atau negatif dihasilkan dari behavioral beliefs, norma subyektif atau tekanan sosial yang dipersepsikan (perceived social pressure) dihasilkan dari normative beliefs, dan control beliefs menimbulkan kontrol keperilakuan yang dipersepsikan. Penelitian lainnya (Bobek dan Hatfield 2003; Tarjo 2009) menyatakan bahwa sikap dan norma subyektif berpengaruh signifikan terhadap niat berperilaku tidak patuh, sedangkan kontrol perilaku yang dipersepsikan tidak berpengaruh signifikan terhadap niat berperilaku tidak patuh.

Semakin positif sikap dan norma subyektif seseorang, dan semakin besar kontrol perilaku yang dipersepsikan, maka semakin kuat niat seseorang tersebut untuk memunculkan perilaku tertentu (Ajzen 2006). Niat tersebut akan terbentuk menjadi perilaku jika terdapat kesempatan untuk berperilaku sesuai dengan kondisi actual behavioral control. Jika kondisi yang sebenarnya tidak memungkinkan muncul perilaku sesuai dengan niatnya, maka akan mempengaruhi kontrol perilaku yang dipersepsikan. Hal tersebut selanjutnya akan merubah niat awal seseorang karena pengaruh perilaku yang muncul. 


\section{Gambar 1: Kerangka Theory of Planned Behavior (TPB)}

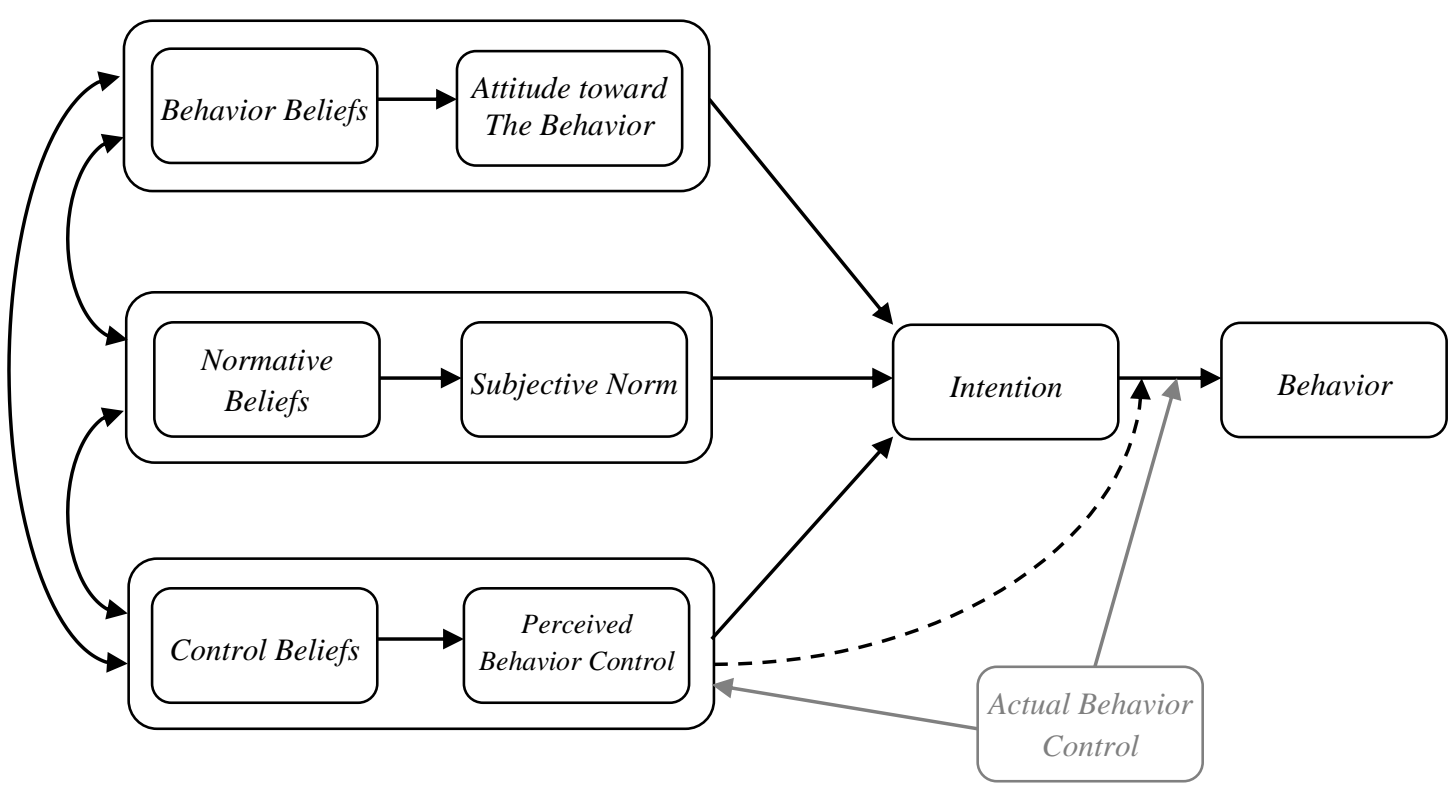

Sumber: Ajzen (2006)

\subsection{Kepatuhan Wajib Pajak}

Kepatuhan berasal dari kata patuh. Menurut Kamus Besar Bahasa Indonesia patuh memiliki pengertian sebagai suka menurut perintah, taat kepada perintah atau aturan, dan berdisiplin.

Menurut Peraturan Menteri Keuangan Nomor 74/PMK.03/2012, kriteria wajib pajak yang dapat dikatakan patuh adalah sebagai berikut:

a. tepat waktu dalam menyampaikan Surat Pemberitahuan (SPT),

b. tidak mempunyai tunggakan pajak untuk semua jenis pajak, kecuali tunggakan pajak yang telah memperoleh ijin mengangsur atau menunda pembayaran pajak,

c. laporan keuangan diaudit oleh akuntan publik atau lembaga pengawas keuangan pemerintah dengan pendapat wajar tanpa pengecualian selama tiga tahun berturut-turut, dan

d. tidak pernah dipidana karena melakukan tindak pidana di bidang perpajakan berdasarkan putusan pengadilan yang telah mempunyai kekuatan hokum tetap dalam jangka waktu lima tahun terakhir.

Mustikasari (2007) menyatakan bahwa wajib pajak dikatakan patuh apabila:

1. benar dalam penghitungan pajak terutang,

2. benar dalam pengisian formulir SPT,

3. tepat waktu, dan

4. melakukan kewajibannya dengan sukarela (atas kesadaran sendiri) sesuai dengan peraturan perpajakan yang berlaku di Indonesia. 


\subsection{PP No. 46 Tahun 2013}

Ketentuan Pajak Penghasilan yang diatur dalam Peraturan Pemerintah (PP) Nomor 46 Tahun 2013, merupakan kebijakan Pemerintah yang mengatur mengenai Pajak Penghasilan atas penghasilan dari usaha yang diterima atau diperoleh wajib pajak yang memiliki peredaran bruto tertentu. Objek pajak yang dikenai Pajak Penghasilan (PPh) dalam peraturan ini adalah Penghasilan dari usaha yang diterima atau diperoleh Wajib Pajak dengan peredaran bruto (omzet) yang tidak melebihi Rp 4,8 miliar dalam 1 tahun Pajak. Peredaran bruto (omzet) merupakan jumlah peredaran bruto (omzet) semua gerai/counter/outlet atau sejenisnya baik pusat maupun cabangnya. Usaha meliputi usaha dagang, industri, dan jasa, seperti misalnya toko/kios/los kelontong, pakaian, elektronik, bengkel, penjahit, warung/rumah makan, salon, dan usaha lainnya. Usaha yang memiliki peredaran bruto maksimal Rp 4,8 miliar biasanya merupakan jenis usaha mikro, kecil dan menengah (UMKM). Tarif pajak peraturan ini sebesar satu persen dan dikenakan pajak final.

Menurut Undang-undang Nomor 20 Tahun 2008 pengertian UMKM adalah sebagai berikut: a. usaha mikro adalah usaha produktif milik orang perorangan dan/atau badan usaha perorangan yang mempunyai kekayaan bersih tidak melebihi lima puluh juta Rupiah (tidak termasuk tanah dan bangunan tempat usaha) atau memiliki peredaran bruto tidak melebihi tiga ratus juta Rupiah setiap tahunnya,

b. usaha kecil adalah usaha ekonomi produktif yang berdiri sendiri, yang dilakukan oleh orang perorangan atau badan usaha yang bukan merupakan anak perusahaan atau bukan cabang perusahaan yang dimiliki, dikuasai, atau menjadi bagian baik langsung maupun tidak langsung dari usaha menengah atau usaha besar yang memiliki kekayaan bersih lima puluh juta Rupiah sampai lima ratus juta Rupiah atau memiliki peredaran bruto tiga ratus juta sampai Rp 2,5 miliar per tahun, dan

c. usaha menengah adalah usaha ekonomi produktif yang berdiri sendiri, yang dilakukan oleh orang perseorangan atau badan usaha yang bukan merupakan anak perusahaan atau cabang perusahaan yang dimiliki, dikuasai, atau menjadi bagian baik langsung maupun tidak langsung dengan usaha kecil atau usaha besar dengan jumlah kekayaan bersih lima ratus juta sampai sepuluh miliar atau hasil penjualan Rp 2,5 miliar sampai lima puluh miliar Rupiah per tahun.

Kriteria objek pajak yang tidak dikenai PPh ini adalah sebagai berikut:

a) penghasilan dari jasa sehubungan dengan pekerjaan bebas, seperti misalnya: dokter, advokat/pengacara, akuntan, notaris, PPAT, arsitek, pemain musik, pembawa acara, dan sebagaimana diuraikan dalam penjelasan PP tersebut, 
b) penghasilan dari usaha yang dikenai PPh Final (pasal 4ayat (2)), seperti misalnya sewa kamar kos, sewa rumah, jasa konstruksi (perencanaan, pelaksanaan dan pengawasan), PPh usaha migas, dan lain sebagainya yang diatur berdasarkan Peraturan Pemerintah tersendiri, dan

c) penghasilan yang diterima atau diperoleh dari luar negeri.

Subjek pajak yang dikenai Pajak Penghasilan sesuai PP Nomor 46 Tahun2013, adalah:

a) orang pribadi, dan

b) badan, tidak termasuk Bentuk Usaha Tetap (BUT) yang menerima penghasilan dari usaha dengan peredaran bruto (omzet) yang tidak melebihi Rp 4,8miliar dalam satu Tahun Pajak.

Yang tidak dikenai Pajak Penghasilan sesuai PP Nomor 46Tahun 2013 adalah:

a) orang pribadi yang melakukan kegiatan usaha perdagangan dan/atau jasa yang menggunakan sarana yang dapat dibongkar pasang dan menggunakan sebagian atau seluruh tempat untuk kepentingan umum (misalnya: pedagang keliling, pedagang asongan, warung tenda di area kaki-lima, dan sejenisnya), dan

b) badan yang belum beroperasi secara komersial atau yang dalam jangka waktu satu tahun setelah beroperasi secara komersial memperoleh peredaran bruto (omzet) melebihi Rp 4,8 miliar.

Wajib Pajak Orang Pribadi atau Badan yang tidak dikenai PPh sesuai PP Nomor 46 Tahun 2013 dikenai kewajiban perpajakan sesuai ketentuan Perpajakan (UU KUP maupun UU PPh secara umum).

\subsection{Rumusan Hipotesis}

2.4.1. Pengaruh antar variabel sikap, norma subyektif, dan kontrol perilaku yang dipersepsikan

Kerangka kerja konseptual Ajzen digunakan untuk menghadapi kompleksitas perilaku sosial manusia (Ajzen 1991). Penelitian ini menggunakan perilaku patuh wajib pajak orang pribadi sebagai perilaku sosial manusia. Model TPB yang dicetuskan Ajzen menjelaskan bahwa terdapat interaksi antar variabel sikap, norma subyektif, dan kontrol perilaku yang dipersepsikan. Namun ketiga variabel tersebut didasari oleh behavior belief, normative belief, dan control belief yang saling berinteraksi secara bolak-balik. Sehingga, hipotesis penelitian yang diajukan yaitu:

$\mathrm{H}_{1}$ : Terdapat hubungan yang saling mempengaruhi antara sikap berperilaku patuh dengan norma subyektif.

$\mathrm{H}_{2}$ : Terdapat hubungan yang saling mempengaruhi antara norma subyektif dengan kontrol perilaku yang dipersepsikan. 
$\mathrm{H}_{3}$ : Terdapat hubungan yang saling mempengaruhi antara sikap berperilaku patuh dengan kontrol perilaku yang dipersepsikan.

\subsubsection{Pengaruh sikap berperilaku terhadap niat berperilaku}

Sikap merupakan bentuk evaluasi atau reaksi perasaan (Ajzen 1991). Ukuran sikap untuk memprediksi perilaku harus sesuai dengan kriteria perilaku niat dalam tindakan, target, konteks, dan elemen-elemen waktu (Ajzen dan Fishbein 1980). Tarjo (2009) mengatakan bahwa sikap ketidakpatuhan pajak akan terbentuk apabila wajib pajak mempunyai keyakinan dan evaluasi yang positif terhadap ketidakpatuhan pajak. Sikap terhadap kepatuhan pajak merupakan perasaan positif atau negatif yang ditunjukkan oleh wajib pajak terhadap kepatuhan perpajakan. Selain itu, Rangkuti dalam Mas'ud (2012) menyatakan bahwa sikap merupakan suatu kecenderungan untuk berperilaku dan dapat dipengaruhi oleh situasi. Situasi yang mendukung atau positif akan menunjukkan niat patuh yang tinggi pula. Penelitian Bobek dan Hatfield (2003) dan Tarjo (2009) membuktikan bahwa sikap terhadap ketidakpatuhan pajak berpengaruh signifikan terhadap niat ketidakpatuhan pajak. Menurut Tarjo (2009) seseorang yang memiliki sikap positif atau mendukung terhadap ketidakpatuhan pajak, maka akan menimbulkan niat untuk melakukan ketidakpatuhan pajak. Selain itu, Pangestu (2011) juga menyatakan bahwa sikap berpengaruh signifikan terhadap niat wajib pajak untuk patuh. Semakin tinggi atau positif sikap terhadap kepatuhan wajib pajak, maka akan berbanding lurus dengan niat untuk berperilaku patuh. Hipotesis penelitian yang diajukan adalah:

$\mathrm{H}_{4}$ : $\quad$ Sikap berperilaku patuh berpengaruh terhadap niat wajib pajak orang pribadi pelaku usaha berperilaku patuh.

\subsubsection{Pengaruh norma subyektif terhadap niat berperilaku}

Menurut Ajzen (1991) norma subjektif adalah persepsi individu tentang pengaruh sosial dalam membentuk perilaku tertentu. Norma subyektif merupakan fungsi dari harapan yang dipersepsikan individu dimana satu atau lebih orang di sekitarnya (misalnya, saudara, teman sejawat) menyetujui perilaku tertentu dan memotivasi individu tersebut untuk mematuhi mereka. Norma-norma subyektif merujuk kepada keyakinan seseorang tentang apakah individu atau kelompok tertentu menyetujui atau menolak individu tersebut melakukan perilaku yang spesifik, dan sejauh mana individualis termotivasi untuk menyesuaikan diri dengan individu atau kelompok lain tersebut. Norma subyektif dapat dinilai secara langsung atau dengan mempertimbangkan keyakinan yang mendasari penilaian individu norma subyektif. Norma subyektif merupakan pengaruh sosial yang mempengaruhi seseorang untuk berperilaku. 
Seseorang akan memiliki keinginan terhadap suatu obyek atau perilaku seandainya ia terpengaruh oleh orang-orang sekitar untuk melakukannya atau ia meyakini bahwa lingkungan atau orang-orang di sekitarnya mendukung terhadap apa yang ia lakukan (Mas'ud 2012). Indikator norma subyektif yang digunakan oleh Bobek dan Hatfield (2003) adalah anggota keluarga, pimpinan perusahaan, teman, dan pasangan; sedangkan Mustikasari (2007) menggunakan indikator teman, konsultan pajak dan petugas pajak. Penelitian Bobek dan Hatfield (2003), Mustikasari (2007), dan Tarjo (2009) membuktikan bahwa secara empiris norma subyektif positif signifikan mempengaruhi niat berperilaku tidak patuh. Hipotesis penelitian yang diajukan yaitu:

$\mathrm{H}_{5}$ : Norma subyektif berpengaruh terhadap niat wajib pajak orang pribadi pelaku usaha berperilaku patuh.

\subsubsection{Pengaruh kontrol perilaku yang dipersepsikan terhadap niat berperilaku}

Ajzen (2006) mengatakan bahwa kontrol keperilakuan mempengaruhi niat didasarkan atas asumsi bahwa kontrol keperilakuan yang dipersepsikan oleh individu akan memberikan implikasi motivasi pada orang tersebut. Dalam arti bahwa, niat akan terbentuk apabila individu merasa mampu untuk menampilkan perilaku. Semakin besar kontrol perilaku yang dipersepsikan, maka akan semakin kuat juga niat para wajib pajak untuk patuh. Bobek dan Hatfield (2003) menyatakan kontrol keperilakuan yang dipersepsikan dalam konteks perpajakan adalah seberapa kuat tingkat kendali yang dimiliki seorang wajib pajak dalam memunculkan perilaku tertentu, seperti melaporkan penghasilannya lebih rendah, mengurangkan beban yang seharusnya tidak boleh dikurangkan ke penghasilan, dan perilaku ketidakpatuhan pajak lainnya. Ajzen dalam Nurina (2010) mengatakan bahwa kontrol keperilakuan mempengaruhi niat didasarkan atas asumsi bahwa kontrol keperilakuan yang dipersepsikan oleh individu akan memberikan implikasi motivasi pada orang tersebut. Penelitian Bobek dan Hatfield (2003) dan Tarjo (2009) membuktikan bahwa kontrol perilaku yang dipersepsikan tidak berpengaruh signifikan terhadap niat berperilaku tidak patuh. Namun, berbeda dengan Mustikasari (2007) yang membuktikan bahwa variabel kontrol keperilakuan yang dipersepsikan mempunyai pengaruh total paling besar terhadap variabel niat tax professional untuk berperilaku tidak patuh. Hipotesis penelitian yang diajukan adalah:

$\mathrm{H}_{6}$ : Kontrol perilaku yang dipersepsikan berpengaruh terhadap niat wajib pajak orang pribadi pelaku usaha berperilaku patuh. 


\subsubsection{Pengaruh kontrol perilaku yang dipersepsikan terhadap perilaku}

Selain berpengaruh terhadap niat berperilaku, kontrol perilaku yang dipersepsikan memiliki pengaruh terhadap perilaku secara langsung. Bobek dan Hatfield (2003) menyatakan bahwa kontrol perilaku yang dipersepsikan mengacu pada tingkat kontrol perasaan individu yang terlibat dalam perilaku tertentu. Kontrol keyakinan dan faktor penentu yang mendasari kontrol perilaku yang dipersepsikan, merujuk pada keyakinan individu mengenai ada atau tidaknya sumber daya dan peluang, serta rintangan dan hambatan untuk melakukan perilaku tertentu. Hasil penelitian empiris Bobek dan Hatfield (2003) dan Tarjo (2009) menemukan bahwa pengaruh kontrol keperilakuan yang dipersepsikan terhadap ketidakpatuhan pajak tidak cukup signifikan. Hipotesis penelitian yang diajukan adalah:

$\mathrm{H}_{7}$ : Kontrol perilaku yang dipersepsikan berpengaruh secara langsung terhadap kepatuhan wajib pajak orang pribadi pelaku usaha.

\subsubsection{Pengaruh niat berperilaku patuh terhadap perilaku}

Niat berperilaku merupakan variabel perantara dalam membentuk perilaku (Ajzen 1991). Pada umumnya manusia bertindak sesuai dengan niat yang ditentukan oleh sikap positif perilaku tertentu yang dimiliki individu. Menurut Mustikasari (2007) pada umumnya manusia bertindak sesuai dengan niat atau tendensinya. Indikator niat berperilaku sebagai variabel bebas Bobek dan Hatfield (2003) dan Mustikasari (2007) yaitu kecenderungan dan keputusan. Kecenderungan adalah kecondongan atau tendensi pribadi wajib pajak orang pribadi pelaku usaha untuk patuh atau tidak patuh dalam melaksanakan kewajiban perpajakannya. Keputusan adalah keputusan pribadi yang dipilih wajib pajak orang pribadi pelaku usaha untuk mematuhi atau tidak mematuhi peraturan perpajakan. Bobek dan Hatfield (2003), Mustikasari (2007), dan Tarjo (2009) secara empiris membuktikan bahwa niat berpengaruh secara positif signifikan terhadap ketidakpatuhan pajak. Hipotesis penelitian yang diajukan adalah:

$\mathrm{H}_{8}$ : Niat berperilaku patuh berpengaruh terhadap kepatuhan wajib pajak orang pribadi pelaku usaha.

\section{Metode Penelitian}

\subsection{Populasi, Sampel, dan Teknik Pengambilan Sampel}

Populasi dari penelitian ini adalah semua wajib pajak orang pribadi pelaku usaha yang terdaftar pada KPP Pratama Kota Salatiga. Populasi tersebut dipilih karena adanya penerapan 
peraturan pengenaan pajak penghasilannya bersifat final sebesar satu persen. Pengukuran sampel menggunakan teknik Maximum Likelihood Estimation. Hal itu karena penelitian dianalisis menggunakan model Structural Equation Modeling (SEM). Ukuran sampel yang sesuai jika menggunakan teknik Maximum Likelihood Estimation dalam pemodelan ini antara 100 - 200 sampel (Ghozali dalam Nurina 2010). Jumlah sampel minimal yang ditetapkan adalah lima kali jumlah parameter yang diestimasi (Hair et al. dalam Nurina 2010). Pada penelitian ini kuesioner dibagikan kepada 126 responden. Pengambilan sampel menggunakan teknik Accidental Sampling. Hasil perhitungan sampel dapat dilihat pada tabel 1.

Tabel 1: Hasil Perhitungan Sampel

\begin{tabular}{lc}
\hline Kuesioner: & \\
\hline Dibagikan & 126 \\
- Tidak Kembali & $(6)$ \\
Kembali & 120 \\
- Data Tidak Lengkap & $(17)$ \\
Sampel Akhir & 103 \\
\hline
\end{tabular}

\subsection{Model Penelitian}

Model penelitian dapat dilihat pada gambar 2.

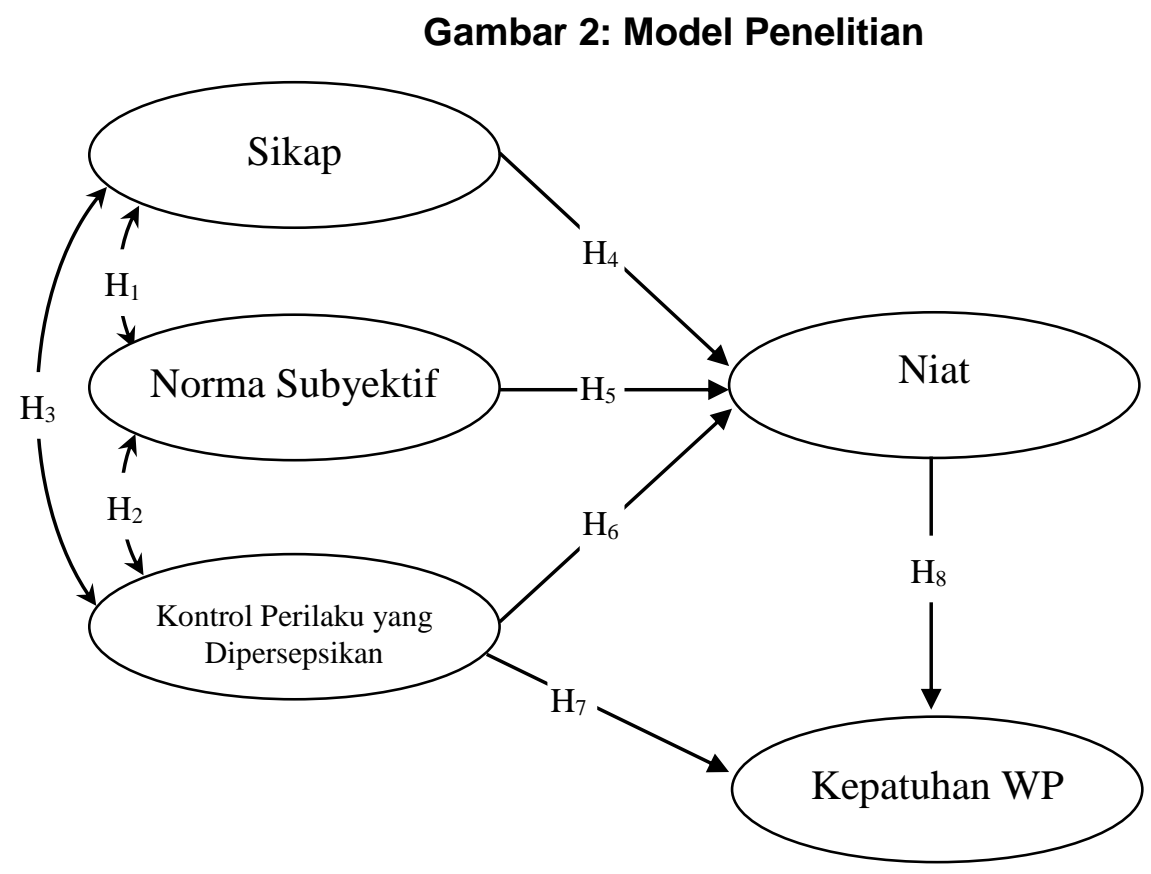




\subsection{Variabel Penelitian dan Pengukurannya}

Tabel 2 menunjukkan dimensi atau indikator yang dipakai dalam penelitian ini, yang diambil dari Mustikasari (2007).

Tabel 2: Variabel dan Dimensi Penelitian

\section{Variabel Penelitian}

Dimensi Penelitian

1. Keinginan membayar pajak sesuai dengan yang seharusnya (pajak terutang)

a. Sikap

2. Pembentukan dana cadangan untuk pemeriksaan pajak

3. Pemanfaatan pajak yang transparan

4. Perasaan diuntungkan oleh sistem perpajakan

5. Biaya suap ke fiskus lebih besar dibanding dengan pajak yang bisa dihemat
b. Norma Subyektif
7. Pengaruh petugas pajak
8. Pengaruh konsultan pajak

6. Pengaruh teman
C. Kontrol Perilaku Dipersepsikan
9. Kemungkinan diperiksa oleh fiskus
10. Kemungkinan dikenai sanksi
11. Kemungkinan pelaporan pihak ketiga

\section{d. Niat Kepatuhan}

\section{e. Perilaku Kepatuhan}

12. Kecenderungan melakukan kepatuhan terhadap ketentuan perpajakan

13. Keputusan untuk melakukan kepatuhan terhadap ketentuan perpajakan

14. Kepatuhan penyerahan SPT (filing compliance)

15. Kepatuhan pembayaran (payment compliance)

16. Kepatuhan pelaporan (reporting compliance)

Variabel yang digunakan dalam penelitian ini terdiri dari tiga variabel eksogen (independen) dan dua variabel endogen (dependen). Variabel-variabel tersebut merupakan pengembangan dari model TPB. Variabel eksogen terdiri dari sikap terhadap kepatuhan pajak, norma subyektif, dan kontrol perilaku yang dipersepsikan. Variabel niat WPOP untuk berperilaku patuh dan kepatuhan WPOP merupakan variabel endogen dari penelitian ini. 


\subsection{Pengujian Hipotesis}

Pengujian hipotesis menggunakan teknik analisis Structural Equation Modeling (SEM) dengan alat bantu program Analysis of Moment Structure (AMOS). Nawangsari (2011) menyatakan bahwa teknik analisis data menggunakan SEM dilakukan untuk menjelaskan secara menyeluruh hubungan antar variabel yang ada dalam penelitian. Dimaksudkan untuk menguji apakah model yang diestimasi mempunyai kesesuaian yang baik dan apakah terdapat hubungan kausalitas seperti yang dihipotesiskan. Terdapat dua pengujian yang dilakukan dalam penelitian ini, yaitu analisis kesesuaian model (Goodness of Fit) dan analisis koefisien jalur.

\subsubsection{Analisis kesesuaian model}

Syarat agar model struktural dikatakan good fit adalah:

(1) Chi Square $\left(X^{2}\right)$ statistic merupakan ukuran buruknya fit suatu model,

(2) nilai level probabilitas minimum adalah 0,1 atau 0,2 ,

(3) nilai The Root Mean Square Error of Approximation (indeks untuk mengkompensasi chi square statistic dalam sampel besar) yang dapat diterima 0,0 sampai 0,08 ,

(4) nilai rasio Normed Chi-Square (CMIN/DF) <2,

(5) tingkat penerimaan Goodness of Fit Index (GFI) $\geq 0,90$,

(6) nilai yang direkomendasikan Adjusted Goodness of Fit Index (AGFI) $\geq 0,90$,

(7) nilai penerimaan yang direkomendasikan Tucker Lewis Index (TLI) $\geq 0,90$, dan

(8) nilai yang direkomendasikan Comparative Fit Index (CFI) adalah $\geq 0,90$.

\subsubsection{Analisis koefisien jalur}

Ghozali (2013) menyatakan bahwa analisis jalur merupakan pengembangan dari model regresi yang digunakan untuk menguji kesesuaian (fit) dari matriks korelasi dua atau lebih model yang dibandingkan. Model yang terbaik dipilih berdasarkan nilai goodness-of-fit. Hubungan antar konstruk yang ditunjukkan dengan garis dan satu anak panah yang menunjukkan hubungan kausalitas (regresi) dari satu konstruk ke konstruk lainnya. Garis dengan dua anak panah menunjukkan hubungan korelasi atau kovarian antar konstruk. Setelah mengembangkan model teoritis dalam diagram jalur, dilakukan penerjemahan model ke dalam persamaan struktural. 


\section{Analisis dan Pembahasan}

\subsection{Demografi Responden}

Data demografi responden dapat dilihat pada tabel 3 berikut.

Tabel 3: Demografi Responden

\begin{tabular}{|c|c|c|c|}
\hline Jenis Kategori & Keterangan & Jumlah Responden & Prosentase \\
\hline 1. Jenis Kelamin & $\begin{array}{ll}\text { a. } & \text { Pria } \\
\text { b. } & \text { Wanita }\end{array}$ & $\begin{array}{l}61 \text { orang } \\
42 \text { orang }\end{array}$ & $\begin{array}{l}59,2 \% \\
40,8 \%\end{array}$ \\
\hline 2. Usia & $\begin{array}{l}\text { a. } 20-40 \text { tahun } \\
\text { b. } 41-60 \text { tahun } \\
\text { c. }>60 \text { tahun }\end{array}$ & $\begin{array}{l}30 \text { orang } \\
61 \text { orang } \\
12 \text { orang }\end{array}$ & $\begin{array}{l}29,1 \% \\
59,2 \% \\
11,7 \%\end{array}$ \\
\hline 3. Pendidikan & $\begin{array}{l}\text { a. SMA } \\
\text { b. Diploma } \\
\text { c. Sarjana } \\
\text { d. Lainnya (SMP) }\end{array}$ & $\begin{array}{l}69 \text { orang } \\
7 \text { orang } \\
23 \text { orang } \\
4 \text { orang }\end{array}$ & $\begin{array}{c}67 \% \\
6,8 \% \\
22,3 \% \\
3,9 \%\end{array}$ \\
\hline 4. Status & $\begin{array}{l}\text { a. Belum Menikah } \\
\text { b. Menikah }\end{array}$ & $\begin{array}{l}19 \text { orang } \\
84 \text { orang }\end{array}$ & $\begin{array}{l}18,5 \% \\
81,5 \%\end{array}$ \\
\hline
\end{tabular}

\subsection{Uji Hipotesis}

Sebelum dilakukan uji hipotesis, sudah dilakukan uji validitas, reliabilitas dan normalitas. Hasil pengujian menunjukkan bahwa data dalam penelitian ini sudah lolos uji validitas, reliabilitas dan normalitas.

\subsubsection{Analisis Kesesuaian Model (Goodness of Fit)}

Evaluasi goodness of fit model penelitian dapat dilihat pada tabel 4 berikut.

Tabel 4: Goodness of Fit Model

\begin{tabular}{lccc}
\hline $\begin{array}{c}\text { Goodness of Fit } \\
\text { Indices }\end{array}$ & Nilai yang Diharapkan & Hasil & Evaluasi Model \\
\hline Chi-Square $\left(\chi^{2}\right)$ & $\begin{array}{c}\leq 119,871, \text { dimana } \chi^{2} \\
\text { dengan df } 96\end{array}$ & 117,222 & Baik \\
$\begin{array}{l}\text { Significant } \\
\text { Probability }(\mathbf{p})\end{array}$ & $\geq 0,05$ & 0,070 & Baik \\
CMIN/DF & $<2$ & 1,221 & Baik \\
GFI & $\geq 0,90$ & 0,880 & Marginal \\
AGFI & $\geq 0,90$ & 0,831 & Marginal \\
\hline TLI & $\geq 0,90$ & 0,934 & Baik \\
CFI & $\geq 0,90$ & 0,947 & Baik \\
\hline
\end{tabular}




\begin{tabular}{lccc}
\hline $\begin{array}{c}\text { Goodness of Fit } \\
\text { Indices }\end{array}$ & Nilai yang Diharapkan & Hasil & Evaluasi Model \\
\hline RMSEA & $\leq 0,08$ & 0,047 & Baik \\
\hline
\end{tabular}

\subsubsection{Analisis Koefisien Jalur}

Analisis koefisien jalur dapat dilihat pada tabel 5 berikut.

Tabel 5: Regression Weights

\begin{tabular}{lcl}
\hline Regression Weights & c.r. & $\mathbf{p}$ \\
\hline Niat $\leftarrow$ sikap & 4.107 & .000 \\
Niat $\leftarrow$ norma & -.970 & .332 \\
Niat $\leftarrow$ kontrol & 2.393 & .017 \\
Kepatuhan $\leftarrow$ kontrol & -2.214 & .027 \\
Kepatuhan $\leftarrow$ niat & 7.869 & .000 \\
\hline
\end{tabular}

Tabel 5 menunjukkan hubungan kausalitas (regresi) antar variabel. Hubungan kausalitas yang signifikan akan ditunjukkan dengan nilai C.R lebih dari 1,96 atau tingkat signifikansi tidak melebihi 5\%. Terdapat hubungan kausalitas dari hasil pengujian di atas yang tidak signifikan, yaitu norma subyektif terhadap niat berperilaku patuh.

Tabel 6: Covariances

\begin{tabular}{ccc}
\hline Covariances & c.r. & p \\
\hline Sikap $<-->$ norma & .274 & .784 \\
Sikap <--> kontrol & -.215 & .830 \\
Norma $<-->$ kontrol & -.289 & .773 \\
\hline
\end{tabular}

Tabel 6 menunjukkan hubungan kovarian antar variabel independen. Ketiga hubungan tersebut memiliki hubungan kovarian yang tidak signifikan karena syarat dari hubungan yang signifikan yaitu nilai C.R. pada koefisien jalur harus melebihi 1,96 atau memiliki tingkat signifikansi di bawah $5 \%$.

Selain itu, terdapat besaran total effect, direct effect, dan indirect effect. Hasil analisis ditunjukkan pada tabel 7, tabel 8, dan tabel 9.

\section{Tabel 7: Standardized Total Effects-Estimates}

\begin{tabular}{lccccc}
\hline & Kontrol & Norma & Sikap & Niat & Kepatuhan \\
\hline Niat & .349 & -.111 & .583 & .000 & .000 \\
Kepatuhan & .196 & -.139 & .730 & 1.251 & .000 \\
\hline
\end{tabular}


Tabel 8: Standardized Direct Effects-Estimates

\begin{tabular}{lccccc}
\hline & Kontrol & Norma & Sikap & Niat & Kepatuhan \\
\hline Niat & .349 & -.111 & .583 & .000 & .000 \\
Kepatuhan & -.241 & .000 & .000 & 1.251 & .000 \\
\hline
\end{tabular}

Tabel 9: Standardized Indirect Effects-Estimates

\begin{tabular}{lccccc}
\hline & Kontrol & Norma & Sikap & Niat & Kepatuhan \\
\hline Niat & .000 & .000 & .000 & .000 & .000 \\
Kepatuhan & .437 & -.139 & .730 & .000 & .000 \\
\hline
\end{tabular}

Ketiga tabel tersebut menunjukkan adanya beberapa kesamaan antara Total Effects dan Direct Effects. Kesamaan tersebut terjadi pada variabel kontrol perilaku yang dipersepsikan, norma subyektif, dan sikap berperilaku patuh terhadap niat berperilaku patuh, serta variabel niat berperilaku patuh terhadap kepatuhan wajib pajak. Masing-masing hubungan memiliki nilai $0,349,-0,111,0,583$, dan 1,251 .

Selain itu terdapat beberapa kesamaan juga antara Total Effects dan Indirect Effects. Variabel norma subyektif terhadap kepatuhan wajib pajak memiliki nilai sebesar $-0,139$ dan variabel sikap berperilaku patuh terhadap kepatuhan wajib pajak yang memiliki nilai sebesar 0,730. Variabel kontrol perilaku yang dipersepsikan terhadap kepatuhan wajib pajak memiliki nilai yang berbeda dari ketiga tabel tersebut. Pada Total Effects memiliki nilai 0,196, pada Direct Effects sebesar -0,241, sedangkan pada Indirect Effects sebesar 0,437.

\subsection{Pembahasan}

Hipotesis pertama, yaitu terdapat hubungan yang saling mempengaruhi antara sikap berperilaku patuh dengan norma subyektif, tidak didukung. Model TPB yang dicetuskan Ajzen menjelaskan bahwa terdapat interaksi antar sikap dengan norma subyektif. Persepsi tekanan sosial dari orang-orang sekitar akan mempengaruhi penilaian positif atau negatif wajib pajak, dan sebaliknya. Namun jika terdapat kecenderungan untuk tidak meyakini orang-orang di sekitarnya, maka persepsi tekanan sosial atau norma subyektif tidak akan mempengaruhi sikap berperilaku patuh wajib pajak.

Hipotesis ke dua, yaitu terdapat hubungan yang saling mempengaruhi antara norma subyektif dengan kontrol perilaku yang dipersepsikan, tidak didukung. Model TPB yang dicetuskan Ajzen menjelaskan bahwa terdapat interaksi antara norma subyektif dengan kontrol perilaku yang dipersepsikan. Tekanan sosial dapat memberikan pengaruh terhadap persepsi atas kontrol perilaku dan sebaliknya. Namun, jika tekanan sosial dari orang-orang sekitar diabaikan, maka kemungkinan-kemungkinan yang terjadi di luar kontrol wajib pajak tidak akan 
mempengaruhi sikap wajib pajak untuk patuh dan tidak akan terbentuk persepsi atas kontrol perilaku tersebut.

Hipotesis ke tiga yaitu terdapat hubungan yang saling mempengaruhi antara sikap berperilaku patuh dengan kontrol perilaku yang dipersepsikan, tidak didukung. Model TPB menjelaskan bahwa terdapat interaksi antar variabel sikap dengan kontrol perilaku yang dipersepsikan. Kontrol keperilakuan yang dipersepsikan dipengaruhi oleh pengalaman masa lalu dan perkiraan seseorang mengenai sulit atau tidaknya untuk melakukan perilaku tertentu (Azwar dalam Burhanudin 2006). Kecenderungan atau sikap untuk berperilaku patuh tidak dipengaruhi oleh persepsi atas kontrol perilaku yang dilakukan jika tidak terdapat pengalaman masa lalu dan perkiraan dari wajib pajak.

Hipotesis ke empat yaitu sikap berperilaku patuh berpengaruh terhadap niat wajib pajak orang pribadi pelaku usaha berperilaku patuh, didukung. Hasil penelitian Pangestu (2011) menunjukkan bahwa sikap berpengaruh terhadap niat wajib pajak untuk patuh. Semakin tinggi atau positif sikap terhadap kepatuhan wajib pajak, maka akan berbanding lurus dengan niat untuk berperilaku patuh. Karena sikap terhadap kepatuhan pajak merupakan perasaan positif atau negatif yang ditunjukkan oleh wajib pajak terhadap kepatuhan perpajakan. Selain itu, Rangkuti dalam Mas'ud (2012) menyatakan bahwa sikap merupakan suatu kecenderungan untuk berperilaku dan dapat dipengaruhi oleh situasi. Situasi yang mendukung atau positif akan menunjukkan niat patuh yang tinggi pula.

Hipotesis ke lima yaitu norma subyektif berpengaruh terhadap niat wajib pajak orang pribadi pelaku usaha berperilaku patuh, tidak didukung. Pangestu (2011) membuktikan bahwa norma subyektif tidak berpengaruh terhadap niat wajib pajak untuk patuh. Semakin tinggi pengaruh norma subyektif, tidak membuat para wajib pajak memiliki niat berperilaku patuh yang tinggi juga. Norma subyektif merupakan pengaruh sosial yang mempengaruhi seseorang untuk berperilaku. Seseorang akan memiliki keinginan terhadap suatu obyek atau perilaku seandainya ia terpengaruh oleh orang-orang sekitar untuk melakukannya atau ia meyakini bahwa lingkungan atau orang-orang di sekitarnya mendukung terhadap apa yang ia lakukan (Mas'ud 2012). Namun, jika wajib pajak merasa pandangan tentang berperilaku patuh merupakan hak pribadinya untuk menentukan kepatuhan dan bukan ditentukan oleh orang lain di sekitarnya, maka wajib pajak tersebut akan mengabaikan pandangan orang tentang kepatuhan. Pada kondisi seperti itu, maka hal tersebut tidak akan mempengaruhi niat berperilaku patuh.

Hipotesis yang ke enam yaitu kontrol perilaku yang dipersepsikan berpengaruh terhadap niat wajib pajak orang pribadi pelaku usaha berperilaku patuh, didukung. Semakin besar kontrol perilaku yang dipersepsikan, maka akan semakin kuat juga niat para wajib pajak untuk patuh. Ajzen dalam Nurina (2010) mengatakan bahwa kontrol keperilakuan mempengaruhi niat 
didasarkan atas asumsi bahwa kontrol keperilakuan yang dipersepsikan oleh individu akan memberikan implikasi motivasi pada orang tersebut.

Hipotesis ke tujuh yaitu kontrol perilaku yang dipersepsikan berpengaruh secara langsung terhadap kepatuhan wajib pajak orang pribadi pelaku usaha, didukung. Kondisi aktual behavioral control memungkinkan muncul kepatuhan yang sesuai dengan niatnya atau sebaliknya. Maka hal ini akan mempengaruhi kontrol perilaku yang dipersepsikan. Penelitian ini tidak mendukung penelitian Bobek \& Hatfield (2003) yang menemukan bahwa pengaruh kontrol perilaku yang dipersepsikan tidak berpengaruh terhadap ketidakpatuhan pajak.

Hipotesis ke delapan yaitu niat berperilaku patuh berpengaruh terhadap kepatuhan wajib pajak orang pribadi pelaku usaha, didukung. Ajzen (1980) menyatakan bahwa niat seseorang untuk melakukan suatu perilaku akan menentukan perilaku tersebut. Hal ini karena kepatuhan yang ditunjukkan para wajib pajak mencerminkan niat untuk berperilaku patuh.

\section{Kesimpulan, Keterbatasan, dan Saran}

Faktor-faktor yang mempengaruhi kepatuhan wajib pajak orang pribadi pelaku usaha sesuai dengan PP No. 46 Tahun 2013 yaitu sikap, kontrol perilaku yang dipersepsikan, dan niat. Penelitian ini menemukan bahwa norma subyektif tidak mempengaruhi kepatuhan wajib pajak orang pribadi pelaku usaha di Salatiga. Selain itu, sikap, norma subyektif, dan kontrol perilaku yang dipersepsikan juga tidak memiliki interaksi yang saling berpengaruh satu sama lain.

Keterbatasasan penelitian ini adalah responden tidak langsung mengisi kuesioner yang diberikan, tetapi minta waktu sampai beberapa hari untuk mengisi kuesioner tersebut karena kesibukan mereka. Sehingga, peneliti tidak dapat mengendalikan jawaban yang diberikan oleh responden jika terdapat ketidakjujuran atau ketidaklengkapan pengisian kuesioner.

Saran untuk penelitian selanjutnya bahwa bisa memilih objek yang lebih luas untuk mendapatkan sampel yang lebih banyak. Selain itu, peneliti selanjutnya dapat menerapkan teori lain atau mengembangkan teori perilaku lainnya, seperti social learning theory.

\section{Daftar Pustaka}

Ajzen, I., \& Fishbein, M. 1980. Understanding Attitudes and Predicting Social Behavior. Englewood Cliffs, NJ: Prentice-Hall.

Ajzen, I. 1991. The Theory of Planned Behavior. Organizational Behavior and Human Decision Processes, 50, 179-211.

Ajzen, I. 2006. Constructing a TPB Questionnaire: Conceptual and Methodological Considerations. 
Bobek, D., dan Richard C. Hatfield. 2003. An Investigation of Theory of Planned Behavior and the Role of Moral Obligation in Tax Compliance. Behavioral Research in Accounting, No. 15: $271-281$.

Burhanudin. 2006. Theory of Planned Behavior: Aplikasi pada Niat Konsumen untuk Berlangganan Surat Kabar Harian Kedaulatan Rakyat di Desa Donotirto, Kecamatan Kretek, Kabupaten Bantul. Karya IImiah. Universitas Janabadra Yogyakarta.

Direktorat Jendral Pajak. 2013. Mahasiswa Untag Antusias Ikuti Seminar Perpajakan. http://www.pajak.go.id/node/7324?lang=en (diakses 10 Juli 2014).

Ghozali, Imam. 2013. Model Persamaan Struktural Konsep dan Aplikasi dengan Program Amos 19.0. Semarang: Badan Penerbit Universitas Diponegoro.

Gusfahmi. 2011. Pajak Menurut Syariah. Edisi Revisi. Jakarta: Rajawali Pers.

Kompas. 2014. Realisasi Pendapatan Pajak 2013 Capai Rp 1.099 Triliun. http://bisniskeuangan.kompas.com/read/2014/01/06/1438185/Realisasi.Pendapatan.Paj ak.2013.Capai.Rp.1.099.Triliun (diakses 28 Maret 2015).

Mas'ud, Muchlis H. 2012. Pengaruh Sikap, Norma-norma Subyektif dan Kontrol Perilaku yang Dipersepsikan Nasabah Bank Terhadap Keinginan Untuk Menggunakan Automatic Teller Machine (ATM) Bank BCA di Kota Malang. Jurnal Manajemen dan Akuntansi Vol. 1 No. 3 (Desember): 13-28.

Mustikasari, Elia. 2007. Kajian Empiris Tentang Kepatuhan Wajib Pajak Badan di Perusahaan Industri Pengolahan di Surabaya. Simposium Nasional Akuntansi X.

Nawangsari, Albertin Yunita. 2011. Structural Equation Modeling pada Perhitungan Indeks Kepuasan Pelanggan dengan Menggunakan Software AMOS (Studi Kasus: Perhitungan Indeks Kepuasan Mahasiswa FMIPA UNY terhadap Operator IM3). Skripsi. Universitas Negeri Yogyakarta.

Neraca. 2014. Ditjen Pajak Bidik Sektor UMKM.http://www.neraca.co.id/article/39455/DitjenPajak-Bidik-Sektor-UMKM (diakses 28 Maret 2015).

Nurina, Latifah. 2010. Kajian Empiris tentang Kepatuhan Wajib Pajak Orang Pribadi di Kota Surakarta. Fakultas Ekonomi. Universitas Sebelas Maret. Surakarta.

Pangestu, Ferdyant., dan Oman Rusmana. 2011. Analisis Faktor-faktor yang Berpengaruh terhadap Tax Compliance Penyetoran SPT Masa. Fakultas Ekonomi. Universitas Jenderal Soedirman. Purwokerto.

Peraturan Menteri Keuangan Republik Indonesia Nomor 74/PMK.03/2012.

Peraturan Pemerintah Republik Indonesia Nomor 46 Tahun 2013.

Ramdhani, Neil. 2007. Model Perilaku Penggunaan IT. https://ml.scribd.com/doc/183447610/neila-buletin-pdf (diakses 16 Desember 2014).

Sulistiyono, Adincha Ayuvisda. 2012. Pengaruh Motivasi terhadap Kepatuhan Wajib Pajak dalam Membayar Pajak Penghasilan Orang Pribadi Usahawan. http://ejournal.unesa.ac.id/index.php/jurnal-akuntansi/article/view/312 (diakses 7 Mei 2014). 
Syahdan, Shaiful Anuar, dan Asfida Parama Rani. 2013. Dimensi Keadilan atas Pemberlakuan PP No. 46 Tahun 2013 dan Peningkatan Kepatuhan Wajib Pajak. Prosiding Simposium Nasional Perpajakan 4, Trunojoyo.

Tarjo. 2009. Analisis Faktor-faktor yang Mempengaruhi Perilaku Ketidakpatuhan Wajib Pajak Orang Pribadi di Bangkalan. Simposium Nasional Perpajakan 2, Trunojoyo.

Tribunnews. 2014. Potensi Penerimaan Pajak dari UMKM Rp 75 Triliun per Tahun.

http://www.tribunnews.com/bisnis/2014/04/17/potensi-penerimaan-pajak-dari-umkm-rp75-triliun-per-tahun (diakses 20 Mei 2014).

Undang-Undang Republik Indonesia Nomor 20 Tahun 2008 tentang Definisi UMKM.

William. 2012. Identifikasi dan Penyelesaian Masalah pada UKM Meubel. Jurnal IImiah Mahasiswa Akuntansi Vol. 1 No. 2 (Maret): 63-68. 